\title{
Korea's STEM Research Analysis Based on Publications in the Web of Science, 1968-2012
}

\author{
Byungkyu Kim \\ Information Service Center, Korea \\ Institute of Science and Technology \\ Information, Korea \\ E-mail: yourovin@kisti.re.kr
}

\author{
Minho So \\ Korea Advanced Institute of Science \\ and Technology, Korea \\ E-mail: minhoso@kaist.ac.kr
}

\author{
Seon-heui Choi* \\ Information Service Center, Korea \\ Institute of Science and Technology \\ Information, Korea \\ E-mail: sunny.choi@kisti.re.kr
}

\begin{abstract}
Korean researchers' scientific outputs are increasing rapidly with the growth of both Korea's economy and industry size. This is the time to analyze the scientific output (STEM area) of Korea over the last 40 years. For this analysis, this study used the SCIE database of Web of Science (WoS), which is a representative global Citation Index Service. The objects of analysis are every Korean document published in the SCIE journal, and the research scopes are (1) analysis of citation and subject categories and (2) analysis of co-authorship. Through this study, characteristics such as cited trend and research trend by subject, and the status of collaboration between Korea and other countries including the 50 states of the USA were revealed.
\end{abstract}

Keywords: Bibliometrics, STEM research, Web of Science, Korea

\section{INTRODUCTION}

South Korea (hereafter Korea) is one of the countries that has developed swiftly during the last half century. The number of patents and scholarly publications in the Science, Technology, Engineering and
Medicine (STEM) disciplines corresponds with the increase in economy and industry. During the last ten years, the position of Korea's publications in the WoS SCIE database increased, and moved to 10th place (3.41\%) in 2012 compared with 14 th place (1.4\%) in 2003. Korea is considered a new center

\section{Open Access}

Accepted date: March 6, 2014

Received date: November 18, 2013

*Corresponding Author: Seon-heui Choi

Principal researcher

Information Service Center

Korea Institute of Science and Technology

Information, Korea

E-mail: sunny.choi@kisti.re.kr
All JISTaP content is Open Access, meaning it is accessible online to everyone, without fee and authors' permission. All JISTaP content is published and distributed under the terms of the Creative Commons Attribution License (http:/ creativecommons. org/licenses/by/3.0/). Under this license, authors reserve the copyright for their content; however, they permit anyone to unrestrictedly use, distribute, and reproduce the content in any medium as far as the original authors and source are cited. For any reuse, redistribution, or reproduction of a work, users must clarify the license terms under which the work was produced. 
for scientific research because of the fast increase of Korea's scientific output (Leydesdorff \& Zhou, 2005). Therefore, the research-to-analysis of international scholarly publications in Korea overall is important.

Scholarly publications such as journal articles are considered representative research products in most STEM disciplines because scholars in their academic communities accept them as a formal scholarly communication channel. These can be used as metric tools of research establishments as well as scholarly communication. The representative method is citation analysis.

Citation analysis is a research method of bibliometrics, which investigates the relationship between cited and citing documents. Citation analysis has been a research area because of its usefulness of the methodology and result. There have been many applications of citation analysis, such as user studies, history of science studies, communication patterns of scientists, evaluation of scientific influence and productivity, information retrieval, collection development, studies of document types or use in a field, studies of research trends, and distribution of information resources (Choi, S-K, 1996). In particular, research using citation analysis such as networks among researchers, integration among academic fields, developmental process of academic fields or research trends, and knowledge maps have been productively performed recently (Cho, H-Y, 2010).

Thomson Reuters' (previously ISI) WoS is the first citation index database for citation analysis and is the most well-known in the world. Thomson Reuters' WoS covers a variety of disciplines: Science, Social science, and Arts \& Humanities, and supports citation indices such as SCIE, SSCI, and A\&HCI (classified by subject respectively). Nowadays, Scopus of Elsevier and Google Scholar also offer competitive service based citation index databases. Recently, some researchers have tried to compare and analyze these databases (Meho \& Yang, 2007). Specifically, Thomson Reuters has improved WoS with the mission, "to maintain a database of worldwide scholarly content that helps researchers find the highest quality literature relevant to their work," (Saha et al., 2003) and the database is used for much research related citation analysis.

We made a choice to utilize WoS because the ob- ject of this study is to analyze Korean international scholarly publication produced over the last 40 years. Citation analysis has had limited use in providing basic statistics of citation. However, we focus more on analysis to find out characteristics by subject and co-authorship. Specifically, the objectives of this study are (1) analysis of Korean scholarly publications by citation and subject using the WoS SCIE database, and (2) analysis of co-authorship between Korea and other countries using the WoS SCIE database.

\section{RELATED LITERATURE}

Researchers all around the globe have continued to measure the scientific performance of countries based on the bibliometric method, but now research related to Asian countries has become important (Zhang \& Zhang, 1997; Fukui \& Rahman, 2002; Abrizah \& Wee 2011; Fu \& Ho, 2013). The scope of analysis of this research is generally the distribution of scholarly publications, science disciplines, contributing institutions, and collaboration. Specifically, (Jeenah \& Pouris, 2008; Marshakova-Shaikevich, 2006) Thomson Reuters has published research reports about the emerging research front as well as research performance using various measurements, such as the analysis of citation patterns (Thomson Reuters 2008, 2013).

Korean research for the analysis of performance of national scientific output is very similar to that of other countries, but it can be separated into two approaches according to research material. The first approach is to use international scholarly publications as research materials, such as journal publications in WoS or SCOPUS (Kim 2001, 2005; Kim \& Noh 2011; NSTC 2011; Kim 2012). The second approach is to utilize national journal publications by national publishers, such as academic societies in various areas (Choi \& Kim 2008; Kim \& Choi 2008). Recently, researchers have used Korea's citation index databases, such as KSCI, KCI, and KOMCI, and studies for the comparison of these citation indices is being carried out (Yang \& Lee, 2012).

The most recent study on citation analysis of Korean scientific output has been accomplished by 
using the KSCD (Korea Science Citation Database). ${ }^{1}$ KSCD was developed in 2001 by KISTI (Korea Institute of Science and Technology Information), and it covers high quality journal articles and citation information by Korean publishers. Through this research, the characteristics of domestic scholarly publications were revealed, such as publication status by subject, citation trend, and co-authorship between universities or research institutions (Choi \& Kim, 2012).

The related research in Korea has limitations in focusing on specific areas of science. National journal publications had limited analysis, which made it difficult to discover long term research trends. This study supplements this limitation through using international scholarly publications by Korean researchers during the last 40 years. For the future, utilization of both global citation index databases, such as WoS and SCOPUS, and Korea's citation index databases, such as KSCD, should be considered to analyze Korea's scientific performance concretely.

\section{DATA COLLECTION AND METHOD}

This study focuses on Korean scholarly publications that are indexed by WoS SCIE and uses all types of documents (articles, editorial materials, letters, news items, corrections, notes, and reviews). Other journals' publications are not considered. In the next study, selection of document types and article types has to be considered, based on related research about document type (van Leeuwen, Thed, \& Costas, 2013).

The following steps to retrieve the relevant data were:

(1) Thomson Reuters' EndNote (version 6) is the software tool for publishing and managing bibliographies, which is used to collect data.

(2) Using the search feature, the author address field (key word "Korea") was used as the query command and the citation database "WoS Science Citation Index Expanded (SCI-EX-
PANDED)" was selected (May 2013).

(3) The search retrieved a total number of 493,123 records during the time period 19682012. For efficiency, searches and downloads were completed by each year, and repeated 45 times (1968-2012). Specifically, we added the new type for extraction as Excel format to output styles of EndNote Software.

The sample record from the downloaded data is to ascertain the following (See Table 1).

A collected data set was preprocessed to be able to analyze exact detail. For example, the "Author Address" item in Table 1 was split by countries and 50 states in the case of the "USA" to analyze co-authorship in Korean STEM research. North Korea's publications among collected data were very minimal since there were only 215 , so the data was ignored in the analysis. Specifically, all of the journals $(8,100)$ which contain collected data were classified by subject categories, such as 176 specific categories of WoS and Leydesdorff's 14 subject categories (Leydesdorff \& Rafols, 2009). Microsoft Excel and Tableau Public were utilized as tools for analyzing and drawing charts and maps.

The results of this study are based on only Korean scholarly publications that are indexed by WoS SCIE so that the results cannot be interpreted as representative of the complete Korean scientific output.

\section{RESULTS}

\subsection{Analysis of Korean STEM Research by Citation and Subject Categories}

The number of publications during the period from 1968 to 1980 is considerably fewer compared to the period after 1980, so that this specific analysis has limitations.

As Fig. 1-A shows, Korean publications during the last 30 years have increased consistently. Specifically, the average rate of increase from 1981 to 2012 is $20 \%$

${ }^{1}$ For more information, visit the site: http://ksci.kisti.re.kr. 
Table 1. Sample data from the downloaded data in SCI Database using EndNote Software

\begin{tabular}{|c|c|c|}
\hline Index & Items & Sample Record (article) \\
\hline 1 & Record Number & 215 \\
\hline 2 & Year & 2010 \\
\hline 3 & Date & 31-Dec \\
\hline 4 & Author & Hong, J. W. W., L. C. \\
\hline 5 & Author Address & $\begin{array}{l}\text { Wu, Lc; Ohio State Univ, Coll Med \& Publ Hlth, Dept Mol \& Cellular Biochem, Columbus, OH } \\
43210 \text { USA;Ohio State Univ, Coll Med \& Publ Hlth, Dept Mol \& Cellular Biochem, Columbus, } \\
\text { OH } 43210 \text { USA;Ohio State Univ, Coll Med \& Publ Hlth, Dept Internal Med, Columbus, OH } \\
43210 \text { USA;Kyung Hee Univ, Grad Sch EW Med Sci, Yongin 446701, South Korea }\end{array}$ \\
\hline 6 & Title & ZAS3 represses NF kappa B-dependent transcription by direct competition for DNA binding \\
\hline 7 & ISBN/ISSN & $1976-6696$ \\
\hline 8 & Journal/Secondary Title & Journal/Bmb Reports \\
\hline 9 & Alternate Journal/Title & $\begin{array}{l}\text { Alternate Journal/ZAS3 represses NF kappa B-dependent transcription by direct competition } \\
\text { for DNA binding }\end{array}$ \\
\hline 10 & Volume & 43 \\
\hline 11 & Number & 12 \\
\hline 12 & Pages & $807-812$ \\
\hline 13 & Keywords & $\begin{array}{l}\text { DNA competition;kappa b-motif-binding proteins;nf kappa b;transcriptional repression;zas3;z- } \\
\text { inc-finger protein;gene-expression;domain;activation;cancer;cells;krc;p65 }\end{array}$ \\
\hline 14 & Abstract & $\begin{array}{l}\text { NF kappa B and ZAS3 are transcription factors that control important cellular processes includ- } \\
\text { ing immunity, cell survival and apoptosis. Although both proteins bind the kappa B-motif, they } \\
\text { produce opposite physiological consequences; NF kappa B activates transcription, promotes cell } \\
\text { growth and is often found to be constitutively expressed in cancer cells, while ZAS3 generally } \\
\text { represses transcription, inhibits cell proliferation and is down-regulated in some cancers. Here, } \\
\text { we show that ZAS3 inhibits NF kappa B-dependent transcription by competing with NF kappa } \\
\text { B for the kappa B-motif. Transient transfection studies show that N-terminal } 645 \text { amino acids } \\
\text { is sufficient to repress transcription activated by NF kappa B, and that the identical region also } \\
\text { possesses intrinsic repression activity to inhibit basal transcription from a promoter. Finally, } \\
\text { in vitro DNA-protein interaction analysis shows that ZAS3 is able to displace NF kappa B by } \\
\text { competing with NF kappa B for the kappa B-motif. It is conceivable that ZAS3 has therapeutic } \\
\text { potential for controlling aberrant activation of NF kappa B in various diseases. [BMB reports } \\
\text { 2010; 43(12): 807-812] }\end{array}$ \\
\hline 15 & Accession Number & WOS:000285816300006 \\
\hline 16 & Notes & 701KH;Times Cited:2;Cited References Count:24 \\
\hline
\end{tabular}

and the median value is $17 \%$. Also, the average rate of increase of the number of references of Korean publications has increased by $3 \%$ so that the average number of references of the year 2012 became 27.1 .
The average increase rate of times cited is $23 \%$, but from 2006, it has continued to drop as shown in Fig. 1-C. The citation ages (i.e., immediacy, peak-time, and half-time of citation) is considered the reason 

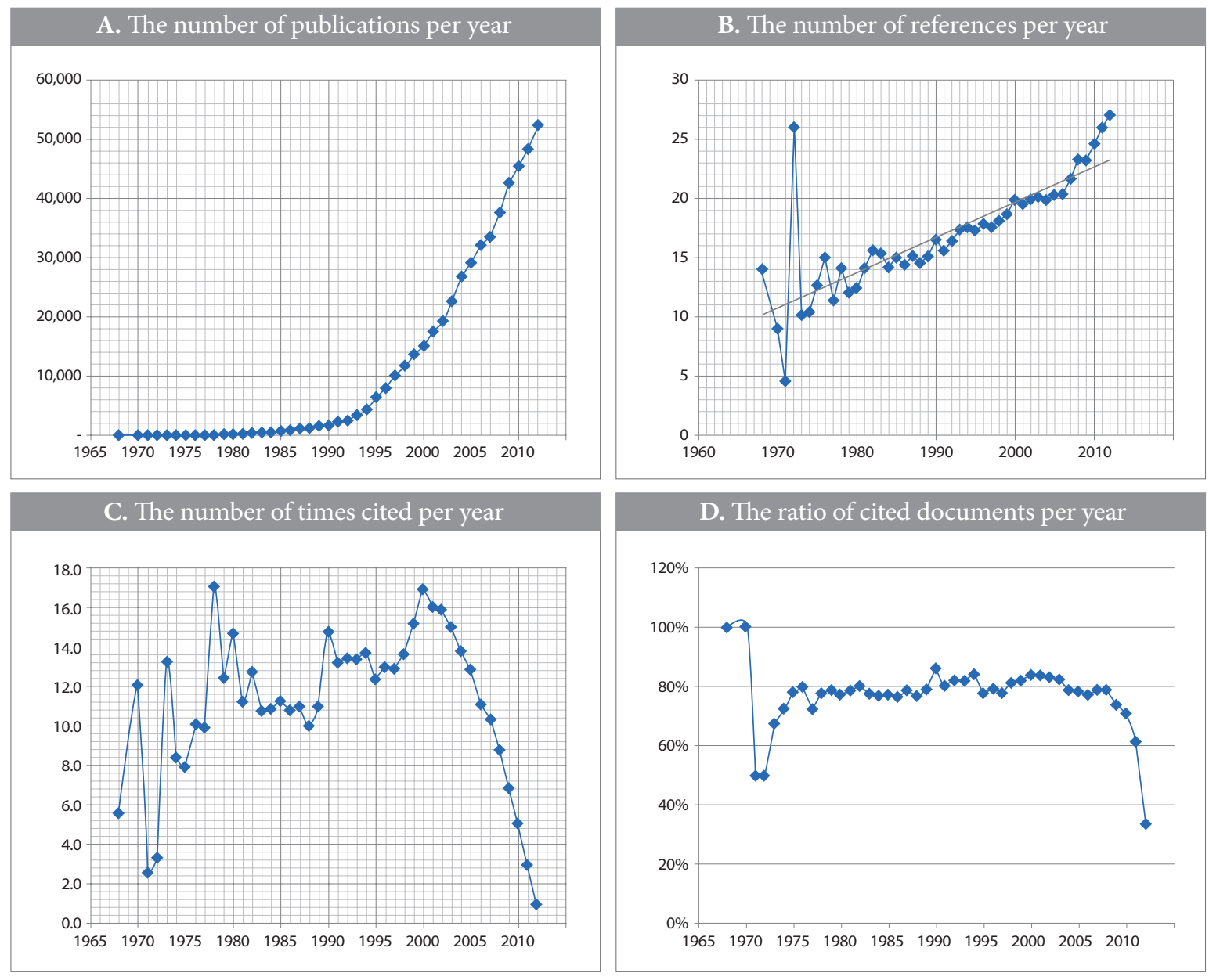

Fig. 1 Basic Status of Citation in Korean STEM Research (1968-2012)

for this syndrome. The related research based on KSCD investigated citation ages by discipline (Choi \& Kim, 2012). However, the research to reveal the exact reason and meaning has yet to be conducted. The average rate of cited percentage as shown in Fig. 1 -D remains around $80 \%$, but went down after the year 2000. The reason for this syndrome is possibly also due to the citation ages.

The analysis of Korean publications by subject categories (14 areas) that Leydesdorff suggested is shown in Fig. 2. This shows scientific output was concentrated to some categories like Biomedical Sciences $18 \%$, Chemistry $17 \%$, Material Sciences $13 \%$, Computer Sciences 12\%, and Clinical Medicine 11\%.

Among the categories with the largest percentage, Chemistry $(30.7 \% \rightarrow 16.0 \%)$ and Material Sciences
$(15.3 \% \rightarrow 13 \%)$ have decreased significantly; on the contrary, the categories that have increased percentage rates are Biomedical Science $(11.1 \% \rightarrow 18.5 \%)$, Clinical Medicine $(7.7 \% \rightarrow 10.3 \%)$, and Computer Sciences $(10.0 \% \rightarrow 13.2 \%)$. Despite sharing a small percentage, the categories that show a large percentage increase rate during the last 30 years are Neurosciences $(0.8 \% \rightarrow 4.4 \%, 238 \%)$, Infectious Diseases $(1.3 \% \rightarrow 2.8 \%, 152 \%)$, Environmental Sciences $(1.1 \% \rightarrow 2.2 \%, 141 \%)$, General Medicine \& Health $(1.3 \rightarrow 2.3 \%, 137 \%)$, and Agriculture $(2.2 \% \rightarrow 3.0 \%$, $133 \%)$.

These characteristics discussed above might be related to the distribution by subject of the WoS database, so additional analysis research is required. 
Correlation between the number of publications and the average number of times cited was not found, as shown in Fig. 3. The categories where the average number of times cited compared to publications are high are: Physics, Infectious diseases, Environment Science, and Geoscience. On the contrary, the categories where the average of times cited compared to publications are low are: Computer Sci- ences, Engineering, General Medicine \& Health, and Agriculture.

The result of the top 20 sub-categories and the number of publications analyzed by WoS subject categories (176 in STEM areas) is shown in Table 2. Top 5 journals by subjects and publications are described in Appendix A.
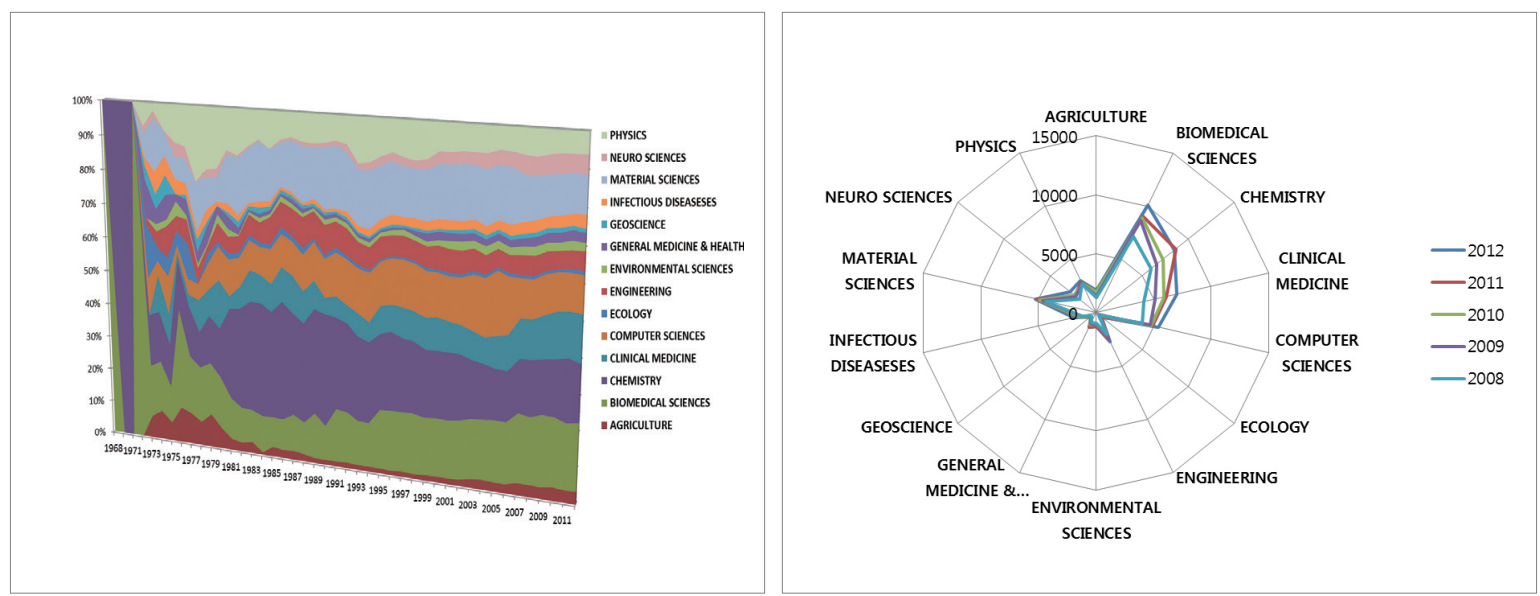

Fig. 2 Number of Documents by 14 Subject Categories Per Year (1968-2012)

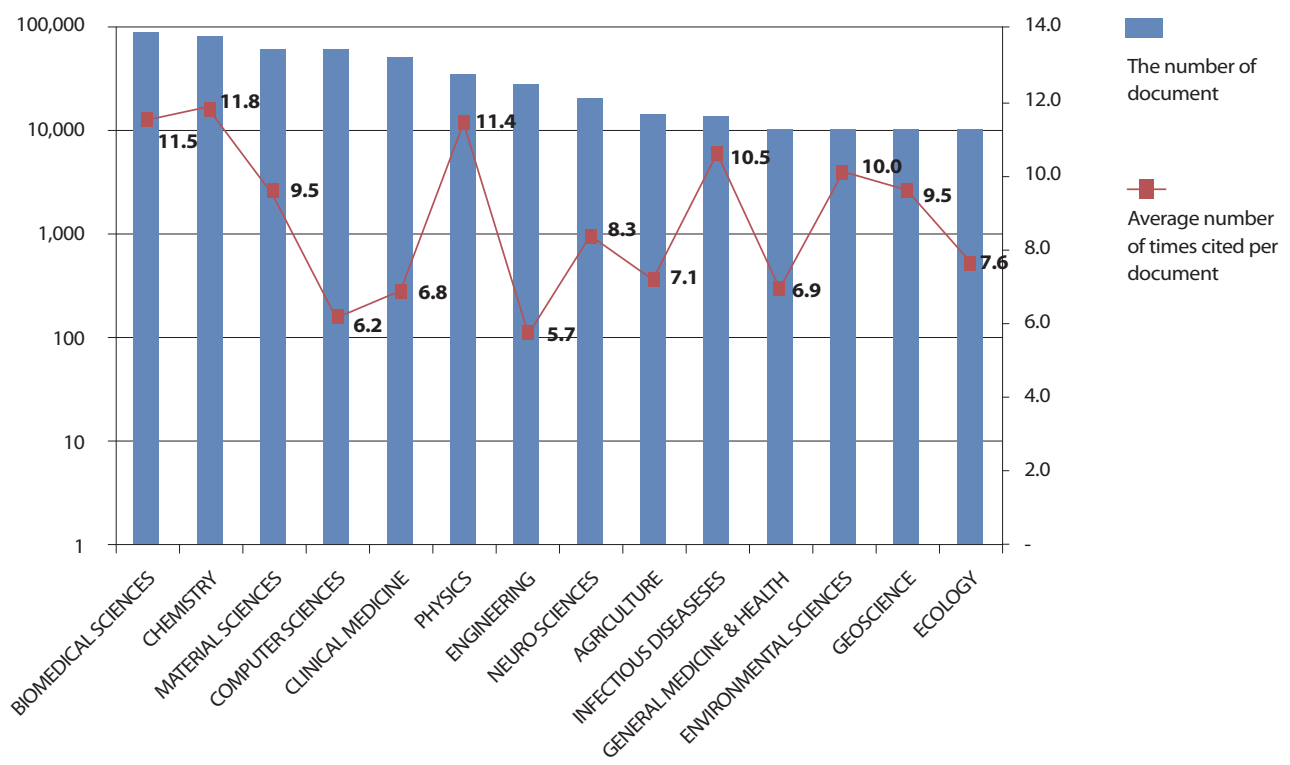

Fig. 3 Publications vs. Times Cited by 14 Subject Categories (1968-2012) 
Table 2. Number of Documents by WoS 176 Categories within Top 20 Categories: Total vs. 2012

\begin{tabular}{|c|c|c|c|}
\hline Ranking & WoS Specific Subject Categories (Top 20) & Year 2012 & Total \\
\hline 1 & CHEMISTRY, MULTIDISCIPLINARY & 3,235 & 30,302 \\
\hline 2 & ENGINEERING, ELECTRICAL \& ELECTRONIC & 2,655 & 28,256 \\
\hline 3 & BIOCHEMISTRY \& MOLECULAR BIOLOGY & 2,322 & 25,212 \\
\hline 4 & MATERIALS SCIENCE, MULTIDISCIPLINARY & 2,171 & 21,960 \\
\hline 5 & PHYSICS, MULTIDISCIPLINARY & 1,106 & 16,048 \\
\hline 6 & PHYSICS, APPLIED & 987 & 14,901 \\
\hline 7 & CHEMISTRY, PHYSICAL & 1,766 & 13,727 \\
\hline 8 & COMPUTER SCIENCE, INFORMATION SYSTEMS & 600 & 10,995 \\
\hline 9 & BIOTECHNOLOGY \& APPLIED MICROBIOLOGY & 932 & 10,975 \\
\hline 10 & CLINICAL NEUROLOGY & 1395 & 10,853 \\
\hline 11 & POLYMER SCIENCE & 636 & 10,248 \\
\hline 12 & ONCOLOGY & 1498 & 9,805 \\
\hline 13 & GASTROENTEROLOGY \& HEPATOLOGY & 1264 & 8,421 \\
\hline 14 & ENGINEERING, MECHANICAL & 638 & 8,269 \\
\hline 15 & CHEMISTRY, MEDICINAL & 692 & 7,211 \\
\hline 16 & CARDIAC \& CARDIOVASCULAR SYSTEMS & 990 & 6,864 \\
\hline 17 & MATHEMATICS & 588 & 6,634 \\
\hline 18 & PHARMACOLOGY \& PHARMACY & 681 & 6,479 \\
\hline 19 & MEDICINE, GENERAL \& INTERNAL & 733 & 6,166 \\
\hline 20 & RADIOLOGY, NUCLEAR MEDICINE \& MEDICAL IMAGING & 632 & 6,086 \\
\hline
\end{tabular}

\subsection{Analysis of Co-authorship in Korean STEM Research}

The number of authors has increased between 1968 and 2012, and the average number of authors per document is 11.4. The result of the analysis for corresponding authors' nationality is shown in Fig. 4.The percentage of publications with Korean corresponding authors investigated is $87 \%$, which is a much higher rate than the percentage of other nationalities. Because the majority of corresponding authors are Korean, this indicates that Korean researchers played a leading role in their publications.
The next highest percentages of corresponding authors from other countries are as follows: the USA, Japan, China, and so on. Specifically, the percentage of corresponding authors' nationality in China has increased recently. This would be related to the increase in China's publications in the WoS SCIE database to 2 nd place (12.09\%) in 2012 compared to 6th place (1.4\%) in 2003. However, further specific research to find the exact reason is required.

The result of analysis for co-authorship with a major county or a group of countries is shown in Fig. 5. Korean researchers share $75 \%$ of independent pub- 
lications and co-authorship is the highest with G7 countries (USA, UK, France, Germany, Italy, Canada); specifically, collaboration research was high among all of the countries. Also, when investigated, it was found that collaborative research (co-authorship) with BRICs (Brazil, Russia, India, China) countries has also increased rapidly. Furthermore, co-authorship has increased between Korea and China consistently, but on the contrary, co-authorship with Japan has continued to decrease. As a result, the ratio of co-authorship has changed. Additional research is required to find the exact reason for this trend.

The result for analysis of co-authorship in scholarly research between Korea and the 50 states in the USA, and the District of Columbia and Puerto Rico, is shown in Fig. 6. The state in the USA that made the most research in publications was found to be California (total number of publications: 13,403; 2012 number of publications: 1,810) and other states such as New York, Maryland, Massachusetts, and Texas followed. The duplication which occurs from co-authorship between Korea and one or more states of the USA were not excluded in Fig. 6.

The last analysis of this study is the investigation for the ratio of co-authorship with other countries by discipline (14 subject categories). The major disciplines that show a high ratio with other countries are Physics (38\%), Environment Sciences (38\%), Ecology (49\%), and Geoscience (55\%). The 10 other disciplines share a ratio composed of over $70 \%$ of independent research by Korean researchers. Specifically, the ratio of Clinical Medicine discipline was analyzed as $85 \%$.

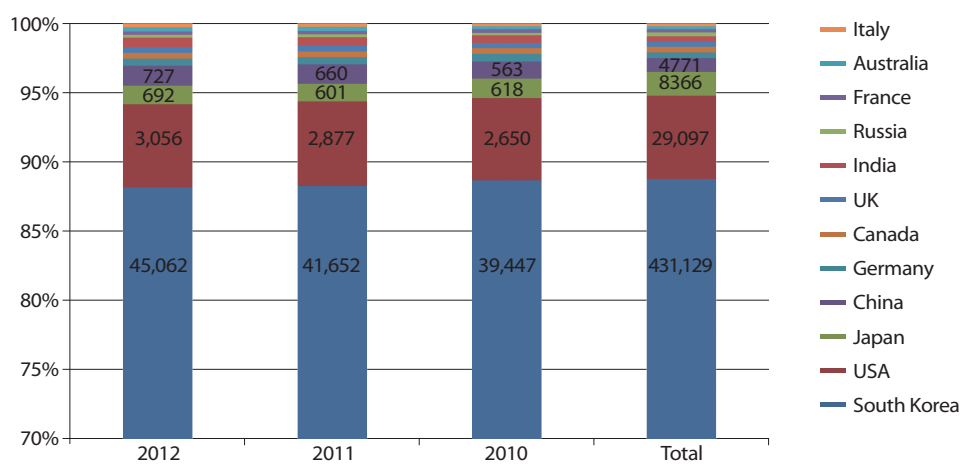

Fig. 4 Percentage of Corresponding Authors by Nationality (1968-2012)

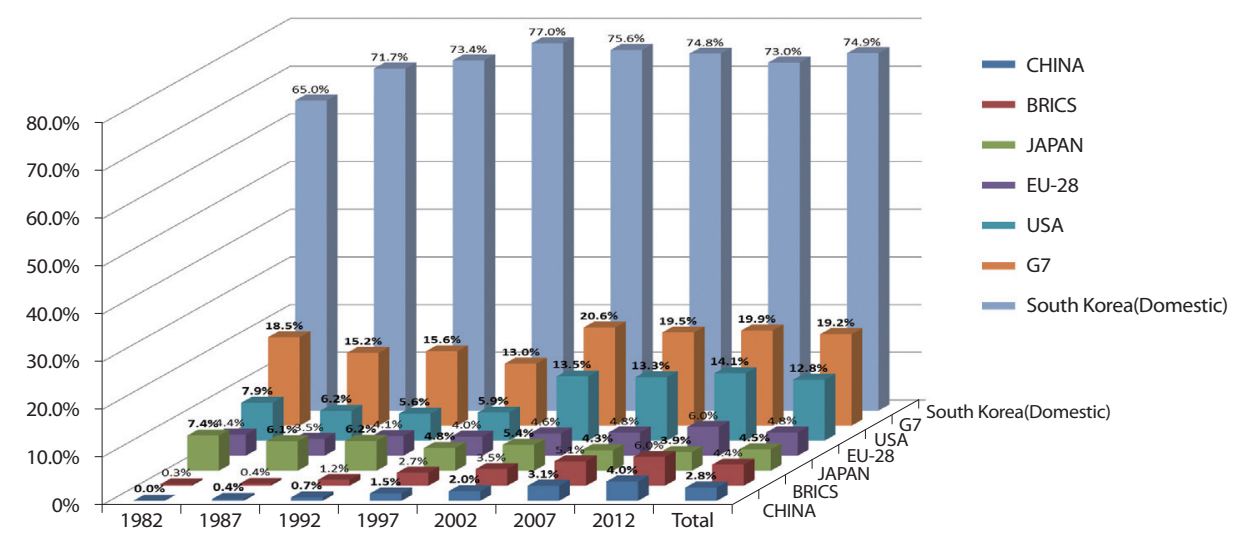

Fig. 5 Percentage of Co-Authorship with Major Countries or a Group of Countries Every 5 Years (1982-2012) 


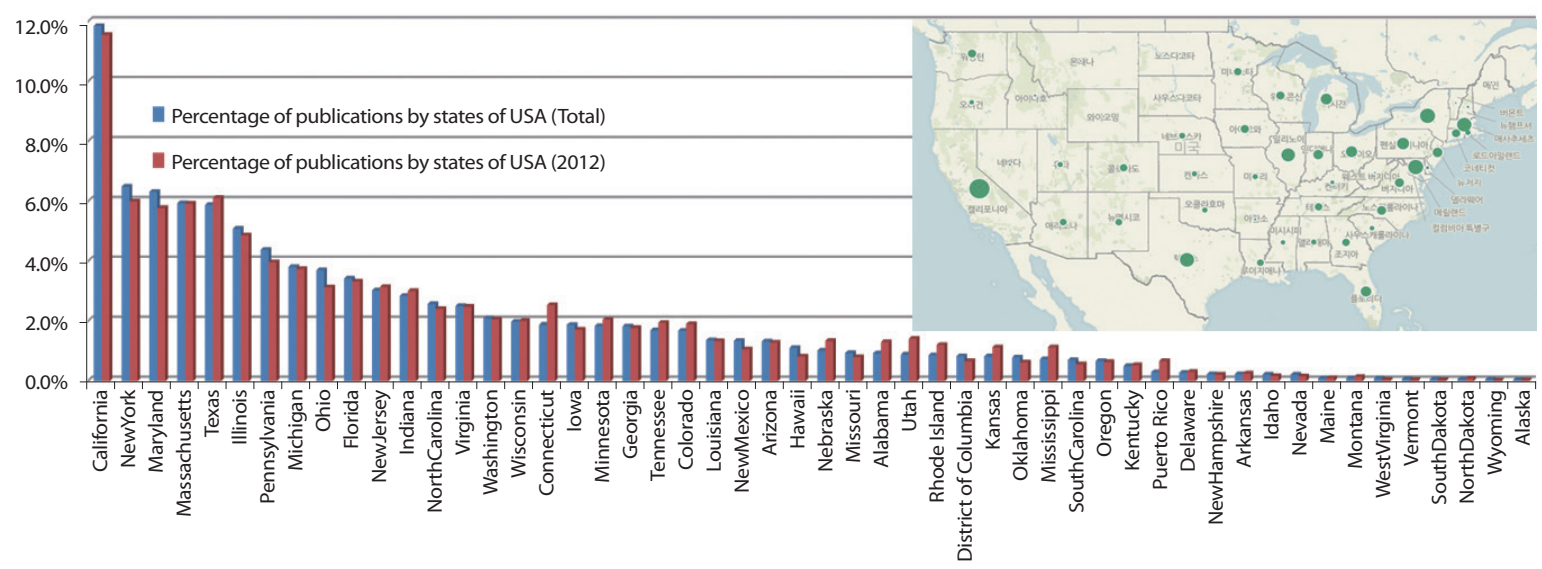

Fig. 6 Co-authorship Between Korea and 50 States/Jurisdictions of USA (1968-2012): Total vs. Year 2012

\section{DISCUSSION AND CONCLUSION}

This study analyzes only those journal publications which researchers consider to be the most representative and trustworthy for analyzing Korean researchers' scientific output in STEM using bibliometric methods during the last 40 years. Specifically, Thomson Reuters' WoS SCIE database is used for citation analysis and EndNote software is utilized to collect the data set. The objective of the research is first, analysis of citation and subject categories and second, analysis of co-authorship. For this, the collected data was pre-processed to add subject classifications on journals using Leydesdorff and WoS subject categories.

The findings of the study are as follows:

(1) After 1980, the number of Korean researchers' publications in STEM has increased 20\% on average, and the average increase of the number of references was $3 \%$. Also, the average increase in times cited with respect to the estimation of the quality was $23 \%$ and the ratio of cited publications was $80 \%$; however, both these numbers have decreased since 2000 . The main cause of this is attributed to the citation ages (i.e., immediacy, peak-time, and half-time of citation), but related research is required to find the exact reason.

(2) The publications were concentrated on disciplines such as Biomedical Sciences (18\%),
Chemistry (17\%), Material Sciences (13\%), Computer Sciences (12\%), and Clinical Medicine $(11 \%)$, and this portion shared $70 \%$.

(3) After 1980, the discipline with the highest percent decrease in publications, among other disciplines, was Chemistry $(30.7 \% \rightarrow 16.0 \%)$. On the other hand, the discipline with the highest percent increase was Biomedical Science $(11.1 \% \rightarrow 18.5 \%)$.

(4) Correlation between the number of publications and the average of times cited was not found. The category where the average of times cited is high was Chemistry (11.8); on the other hand, the category where the average of times cited is low was Engineering (5.7).

(5) The percentage of publications of corresponding authors by country was in the following order: Korea (87\%), USA (7\%), Japan, and China, but China overtook Japan during the last two years.

(6) Independent publications by Korean researchers share $75 \%$ and co-authorship is the highest with G7 countries (USA, UK, France, Germany, Italy, Canada); specifically, collaboration research was high among all of the countries. Also, the syndrome known as collaborate research (co-authorship) with BRIC (Brazil, Russia, India, China) countries has rapidly increased. Specifically, co-authorship has in- 
creased between Korea and China consistently. China's increase overtook Japan during the past two years.

(7) As a result from the analysis of co-authorship between Korea and 50 states in the USA, the state which made the most research in publications was California (12\%).

(8) The categories which are high in the ratio of co-authorship with other countries are Physics (38\%), Environment Sciences (38\%), Ecology (49\%), and Geoscience(55\%). Whereas, the other 10 disciplines share over $70 \%$ of the ratio of independent research by Korean researchers. Specifically, the category in which the ratio of independent research by Korean researchers is the highest was investigated.

For the future, the utilizing of other databases such as KSCD should be considered because this research limited the analysis scope to only the SCIE database. Specifically, as a result from other recent analysis of the composition (rate) by subject between KSCD and SCIE, two compositions were considerably different (Choi \& Kim 2013). Therefore, comparison with $\mathrm{KSCD}$ is required to analyze Korea's scientific performance completely.

\section{REFERENCES}

Abrizah, A., \& Wee, M.-C. (2011). Malaysia's Computer Science research productivity based on publications in the WoS, 2000-2010. Malaysian Journal of Library \& Information Science, 16(1), 109-124.

Bornmann, L., \& Daniel, H.-D. (2008). What do citation counts measure? - A review of studies on citing behavior. Journal of Documentation, 64(1), 45-80.

Choi, H.-N., Kim, B.-K., Jung, Y.-I. \& Choi, S.-H. (2013). Collnet Journal of Scientometrics and Information Management, 7(1), 1-33.

Cho, H.-Y. (2010). A comparative study on researchers' language preference for citing documents in different subject fields. Journal of the Korean BIBLIA Society for Library and Information Science, 21(1), 212-221.

Choi, S.-H., Kim, B.-K., Kang, M.-Y., You, B.-J., Lee, J.,
\& Park, J.-W. (2011). A study of citing patterns of Korean scientists on Korean journals. Journal of the Korean Society for information Management, 28(2), 97-115.

Choi, S.-H., \& Kim, B.-K. (2013). Study on automatic subject classification of Korean Journals using citation index databases. International Conference on Convergence Content 2013, Japan.

Choi, S.-K. (1996). Comparative study on citation analysis in the field of mechanical engineering in Korea and Japan. Journal of the Korean Society for information Management, 13(2), 121-142.

Fu, H.-Z., \& Ho, Y.-S. (2013). Independent research of China in Science Citation Index Expanded during 1980-2011. Journal of Informetrics, 7(1), 210-222.

Fukui, T., \& Rahman, M. (2002). Contribution of research in basic and clinical sciences in Japan. Internal Medicine, 41(8), 626-628.

Kim, B.-K., Kang, M.-Y., Choi, S.-H., Kim, S.-Y., You, B.-J. \& Shin, J.-D. (2011). Citing behavior of Korean scientists on foreign journals in KSCD. Journal of the Korean Society for information Management, 28(2), 117-133.

Kim, M.-J. (2001). A bibliometric analysis of physics publications in Korea 1994-1998. Scientometrics, $50,503-521$.

Kim, M.-J. (2005). Korean science and international collaboration, 1995-2000. Scientometrics, 63(2), 321-339.

Kim, W.-J., Noh, K.-R., Park, M.-S. \& Choi, H.-K. (2011). 2010 SCI analysis research of Korean researchers. KISTI Knowledge Report, 16.

Kim, W.-J. (2012). A study on the factors influencing citation speed and citation frequency of scientific articles using bibliometric analysis in South Korea. Journal of the Korean Society for Library and Information Science, 46(4), 285-306.

King, C., \& Pendlebury, D.A. (2013). Web of Knowledge research fronts 2013: 100 top-ranked specialties in the sciences and social sciences. Thomson Reuters.

Leydesdorff, L., \& Zhou, P. (2005). Are the contribution of China and Korea upsetting the world system of science? Scientometric, 63(3), 617-630.

Leydesdorff, L., \& Rafols, I. (2009). A global map of science based on the ISI subject categories. 
Journal of the American Society for Information Science and Technology, 60(2), 348-362.

National Science \& Technology Commission (2011). SCI Analysis Research.

Meho, L. I., \& Yang, K. (2007). Impact of data sources on citation counts and rankings of LIS faculty: Web of Science versus Scopus and Google Scholar. Journal of the American Society for Information Science and Technology, 58(13), 2105-2125.

Marshakova-Shaikevich, I. (2006). Scientific collaboration of new $10 \mathrm{EU}$ countries in the field of social sciences. Information Processing and Management, 42(6), 1592-1598.

Thomson Reuters (2008). A guide to evaluating research performance with citation data.

Van Leeuwen, T. N., Costas, R., Calero-Medina, C., \& Visser, M. S. (2013). The role of editorial material in bibliometric research performance assessments. Scientometrics, 95(2), 817-828.

Yang, K.-D., \& Lee, J.-W. (2012). Comparative analysis of citation indexes in Korea. Proceedings of the 8th International Conference on WIS (pp. 756762), Seoul: KISTI.

Zhang, H., \& Zhang, Y. (1997). Scientometric study on research performance in China. Information Processing and Management, 33(1), 81-89. 


\section{Appendix A}

Top 5 Journals by Subject Categories: 1968-2012 vs. 2012.

\begin{tabular}{|c|c|c|}
\hline $\begin{array}{l}\text { Subject } \\
\text { Categories }\end{array}$ & Top 5 Journals by Publications (1968-2012) & Top 5 Journals by Publications (2012) \\
\hline \multirow{4}{*}{$\begin{array}{l}\text { BIOMEDICAL } \\
\text { SCIENCES }\end{array}$} & $\begin{array}{l}\text { FASEB JOURNAL } \\
\text { JOURNAL OF MICROBIOLOGY AND } \\
\text { BIOTECHNOLOGY }\end{array}$ & $\begin{array}{l}\text { PLOS ONE } \\
\text { BIOCHEMICAL AND BIOPHYSICAL RESEARCH } \\
\text { COMMUNICATIONS }\end{array}$ \\
\hline & $\begin{array}{l}\text { BIOCHEMICAL AND BIOPHYSICAL RESEARCH } \\
\text { COMMUNICATIONS }\end{array}$ & FASEB JOURNAL \\
\hline & MOLECULES AND CELLS & ANNALS OF ONCOLOGY \\
\hline & JOURNAL OF BIOLOGICAL CHEMISTRY & JOURNAL OF CLINICAL ONCOLOGY \\
\hline \multirow{5}{*}{$\begin{array}{l}\text { MATERIAL } \\
\text { SCIENCES }\end{array}$} & APPLIED PHYSICS LETTERS & APPLIED PHYSICS LETTERS \\
\hline & JAPANESE JOURNAL OF APPLIED PHYSICS & JAPANESE JOURNAL OF APPLIED PHYSICS \\
\hline & JOURNAL OF APPLIED PHYSICS & JOURNAL OF APPLIED PHYSICS \\
\hline & PHYSICAL REVIEW B & CURRENT APPLIED PHYSICS \\
\hline & THIN SOLID FILMS & JOURNAL OF CERAMIC PROCESSING RESEARCH \\
\hline \multirow{5}{*}{$\begin{array}{l}\text { COMPUTER } \\
\text { SCIENCES }\end{array}$} & $\begin{array}{l}\text { NEURAL INFORMATION PROCESSING, PT } 2 \text {, } \\
\text { PROCEEDINGS }\end{array}$ & IEICE TRANSACTIONS ON COMMUNICATIONS \\
\hline & ELECTRONICS LETTERS & ELECTRONICS LETTERS \\
\hline & IEICE TRANSACTIONS ON COMMUNICATIONS & EXPERT SYSTEMS WITH APPLICATIONS \\
\hline & IEEE TRANSACTIONS ON MAGNETICS & IEEE TRANSACTIONS ON MAGNETICS \\
\hline & $\begin{array}{l}\text { IEEE TRANSACTIONS ON CONSUMER } \\
\text { ELECTRONICS }\end{array}$ & $\begin{array}{l}\text { JOURNAL OF ELECTRICAL ENGINEERING \& } \\
\text { TECHNOLOGY }\end{array}$ \\
\hline \multirow{5}{*}{$\begin{array}{l}\text { CLINICAL } \\
\text { MEDICINE }\end{array}$} & AMERICAN JOURNAL OF CARDIOLOGY & $\begin{array}{l}\text { JOURNAL OF GASTROENTEROLOGY AND } \\
\text { HEPATOLOGY }\end{array}$ \\
\hline & JOURNAL OF DENTAL RESEARCH & JOURNAL OF DERMATOLOGY \\
\hline & $\begin{array}{l}\text { JOURNAL OF GASTROENTEROLOGY AND } \\
\text { HEPATOLOGY }\end{array}$ & $\begin{array}{l}\text { JOURNAL OF THE AMERICAN COLLEGE OF } \\
\text { CARDIOLOGY }\end{array}$ \\
\hline & BLOOD & AMERICAN JOURNAL OF CARDIOLOGY \\
\hline & CIRCULATION & GASTROINTESTINAL ENDOSCOPY \\
\hline \multirow{5}{*}{$\begin{array}{l}\text { NEURO } \\
\text { SCIENCES }\end{array}$} & $\begin{array}{l}\text { JOURNAL OF KOREAN NEUROSURGICAL } \\
\text { SOCIETY }\end{array}$ & $\begin{array}{l}\text { JOURNAL OF KOREAN NEUROSURGICAL } \\
\text { SOCIETY }\end{array}$ \\
\hline & NEUROSCIENCE LETTERS & ASIA-PACIFIC PSYCHIATRY \\
\hline & $\begin{array}{l}\text { INVESTIGATIVE OPHTHALMOLOGY \& VISUAL } \\
\text { SCIENCE }\end{array}$ & EUROPEAN JOURNAL OF NEUROLOGY \\
\hline & EUROPEAN NEUROPSYCHOPHARMACOLOGY & NEUROSCIENCE LETTERS \\
\hline & STROKE & JOURNAL OF PHYSICAL THERAPY SCIENCE \\
\hline \multirow{5}{*}{ ECOLOGY } & AQUACULTURE & JOURNAL OF ASIA-PACIFIC ENTOMOLOGY \\
\hline & JOURNAL OF PHYCOLOGY & ENTOMOLOGICAL RESEARCH \\
\hline & JOURNAL OF ASIA-PACIFIC ENTOMOLOGY & ZOOTAXA \\
\hline & FISHERIES SCIENCE & FISH \& SHELLFISH IMMUNOLOGY \\
\hline & FISH \& SHELLFISH IMMUNOLOGY & JOURNAL OF PHYCOLOGY \\
\hline \multirow{5}{*}{ CHEMISTRY } & BULLETIN OF THE KOREAN CHEMICAL SOCIETY & BULLETIN OF THE KOREAN CHEMICAL SOCIETY \\
\hline & $\begin{array}{l}\text { ABSTRACTS OF PAPERS OF THE AMERICAN } \\
\text { CHEMICAL SOCIETY }\end{array}$ & $\begin{array}{l}\text { JOURNAL OF NANOSCIENCE AND } \\
\text { NANOTECHNOLOGY }\end{array}$ \\
\hline & $\begin{array}{l}\text { KOREAN JOURNAL OF CHEMICAL } \\
\text { ENGINEERING }\end{array}$ & JOURNAL OF MATERIALS CHEMISTRY \\
\hline & ARCHIVES OF PHARMACAL RESEARCH & CHEMICAL COMMUNICATIONS \\
\hline & $\begin{array}{l}\text { JOURNAL OF NANOSCIENCE AND } \\
\text { NANOTECHNOLOGY }\end{array}$ & $\begin{array}{l}\text { INTERNATIONAL JOURNAL OF HYDROGEN } \\
\text { ENERGY }\end{array}$ \\
\hline
\end{tabular}




\begin{tabular}{|c|c|c|}
\hline $\begin{array}{l}\text { Subject } \\
\text { Categories }\end{array}$ & Top 5 Journals by Publications (1968-2012) & Top 5 Journals by Publications (2012) \\
\hline \multirow{5}{*}{ GEOSCIENCE } & JOURNAL OF GEOPHYSICAL RESEARCH & JOURNAL OF GEOPHYSICAL RESEARCH \\
\hline & GEOSCIENCES JOURNAL & GEOSCIENCES JOURNAL \\
\hline & GEOPHYSICAL RESEARCH LETTERS & $\begin{array}{l}\text { JOURNAL OF GEOPHYSICAL RESEARCH- } \\
\text { ATMOSPHERES }\end{array}$ \\
\hline & $\begin{array}{l}\text { JOURNAL OF GEOPHYSICAL RESEARCH- } \\
\text { ATMOSPHERES }\end{array}$ & CLIMATE DYNAMICS \\
\hline & GEOCHIMICA ET COSMOCHIMICA ACTA & $\begin{array}{l}\text { ASIA-PACIFIC JOURNAL OF ATMOSPHERIC } \\
\text { SCIENCES }\end{array}$ \\
\hline \multirow{5}{*}{ ENGINEERING } & $\begin{array}{l}\text { JOURNAL OF MECHANICAL SCIENCE AND } \\
\text { TECHNOLOGY }\end{array}$ & $\begin{array}{l}\text { JOURNAL OF MECHANICAL SCIENCE AND } \\
\text { TECHNOLOGY }\end{array}$ \\
\hline & KSME INTERNATIONAL JOURNAL & $\begin{array}{l}\text { INTERNATIONAL JOURNAL OF PRECISION } \\
\text { ENGINEERING AND MANUFACTURING }\end{array}$ \\
\hline & $\begin{array}{l}\text { INTERNATIONAL JOURNAL OF HEAT AND MASS } \\
\text { TRANSFER }\end{array}$ & $\begin{array}{l}\text { INFORMATION-AN INTERNATIONAL } \\
\text { INTERDISCIPLINARY JOURNAL }\end{array}$ \\
\hline & JOURNAL OF SOUND AND VIBRATION & ABSTRACT AND APPLIED ANALYSIS \\
\hline & $\begin{array}{l}\text { INTERNATIONAL JOURNAL OF PRECISION } \\
\text { ENGINEERING AND MANUFACTURING }\end{array}$ & $\begin{array}{l}\text { INTERNATIONAL JOURNAL OF AUTOMOTIVE } \\
\text { TECHNOLOGY }\end{array}$ \\
\hline \multirow{5}{*}{$\begin{array}{l}\text { INFECTIOUS } \\
\text { DISEASESES }\end{array}$} & JOURNAL OF MICROBIOLOGY & JOURNAL OF BACTERIOLOGY \\
\hline & $\begin{array}{l}\text { INTERNATIONAL JOURNAL OF SYSTEMATIC } \\
\text { AND EVOLUTIONARY MICROBIOLOGY }\end{array}$ & TRANSPLANTATION PROCEEDINGS \\
\hline & TRANSPLANTATION PROCEEDINGS & JOURNAL OF IMMUNOLOGY \\
\hline & $\begin{array}{l}\text { JOURNAL OF ALLERGY AND CLINICAL } \\
\text { IMMUNOLOGY }\end{array}$ & $\begin{array}{l}\text { INTERNATIONAL JOURNAL OF SYSTEMATIC } \\
\text { AND EVOLUTIONARY MICROBIOLOGY }\end{array}$ \\
\hline & JOURNAL OF IMMUNOLOGY & JOURNAL OF MICROBIOLOGY \\
\hline \multirow{5}{*}{$\begin{array}{l}\text { ENVIRONMEN- } \\
\text { TAL SCIENCES }\end{array}$} & WATER SCIENCE AND TECHNOLOGY & KSCE JOURNAL OF CIVIL ENGINEERING \\
\hline & JOURNAL OF HAZARDOUS MATERIALS & BIORESOURCE TECHNOLOGY \\
\hline & CHEMOSPHERE & JOURNAL OF HAZARDOUS MATERIALS \\
\hline & BIORESOURCE TECHNOLOGY & ENVIRONMENTAL SCIENCE \& TECHNOLOGY \\
\hline & ATMOSPHERIC ENVIRONMENT & ATMOSPHERIC ENVIRONMENT \\
\hline \multirow{5}{*}{ AGRICULTURE } & FOOD SCIENCE AND BIOTECHNOLOGY & FOOD SCIENCE AND BIOTECHNOLOGY \\
\hline & $\begin{array}{l}\text { ASIAN-AUSTRALASIAN JOURNAL OF ANIMAL } \\
\text { SCIENCES }\end{array}$ & $\begin{array}{l}\text { JOURNAL OF THE KOREAN SOCIETY FOR } \\
\text { APPLIED BIOLOGICAL CHEMISTRY }\end{array}$ \\
\hline & $\begin{array}{l}\text { JOURNAL OF AGRICULTURAL AND FOOD } \\
\text { CHEMISTRY }\end{array}$ & $\begin{array}{l}\text { KOREAN JOURNAL FOR FOOD SCIENCE OF } \\
\text { ANIMAL RESOURCES }\end{array}$ \\
\hline & $\begin{array}{l}\text { KOREAN JOURNAL OF HORTICULTURAL } \\
\text { SCIENCE \& TECHNOLOGY }\end{array}$ & $\begin{array}{l}\text { EVIDENCE-BASED COMPLEMENTARY AND } \\
\text { ALTERNATIVE MEDICINE }\end{array}$ \\
\hline & $\begin{array}{l}\text { KOREAN JOURNAL FOR FOOD SCIENCE OF } \\
\text { ANIMAL RESOURCES }\end{array}$ & $\begin{array}{l}\text { KOREAN JOURNAL OF HORTICULTURAL } \\
\text { SCIENCE \& TECHNOLOGY }\end{array}$ \\
\hline \multirow{5}{*}{ PHYSICS } & JOURNAL OF THE KOREAN PHYSICAL SOCIETY & JOURNAL OF THE KOREAN PHYSICAL SOCIETY \\
\hline & PHYSICAL REVIEW D & OPTICS EXPRESS \\
\hline & PHYSICAL REVIEW LETTERS & PHYSICAL REVIEW D \\
\hline & PHYSICS LETTERS B & PHYSICAL REVIEW LETTERS \\
\hline & OPTICS EXPRESS & JOURNAL OF HIGH ENERGY PHYSICS \\
\hline \multirow{5}{*}{$\begin{array}{l}\text { GENERAL } \\
\text { MEDICINE \& } \\
\text { HEALTH }\end{array}$} & JOURNAL OF KOREAN MEDICAL SCIENCE & JOURNAL OF KOREAN MEDICAL SCIENCE \\
\hline & YONSEI MEDICAL JOURNAL & YONSEI MEDICAL JOURNAL \\
\hline & $\begin{array}{l}\text { JOURNAL OF THE KOREAN MEDICAL } \\
\text { ASSOCIATION }\end{array}$ & $\begin{array}{l}\text { JOURNAL OF THE KOREAN MEDICAL } \\
\text { ASSOCIATION }\end{array}$ \\
\hline & JOURNAL OF KOREAN ACADEMY OF NURSING & JOURNAL OF KOREAN ACADEMY OF NURSING \\
\hline & EPIDEMIOLOGY & VALUE IN HEALTH \\
\hline
\end{tabular}

